\title{
Productivity improvement in the production line with lean manufacturing approach: case study PT. XYZ
}

\author{
Halimatussa'diah*, Ali Parkhan, and Muchamad Sugarindra \\ Industrial Department, Universitas Islam Indonesia, Jl. Kaliurang, Km 14.5, Yogyakarta, Indonesia
}

\begin{abstract}
The increaseing productivity is one of the competitive strategies that can be applied in a company in order to survive in an intense competitive presure. PT. XYZ is a textile industry manufacturing golf gloves and caddy bag. Every day, the company has a production target of 600 pieces per line. However, the desired target is not achieved that it will affect the delay in delivery of products to customers. In this research, a case study on implementing value stream mapping and Kaizen as the lean manufacturing concept is reported. The purpose of this study is to map the current production line, analyse and design the future value stream mapping by eliminating waste occured. It is obtained a lead time reduction as much as 440.4 seconds through eliminating 17 non-value added activities. Then, the output can be increased up to $21 \%$ which is equal to 502 pieces.
\end{abstract}

\section{Introduction}

PT.XYZ is a textile company that manufactures golf glove as primary production. In conducting the production process, the company has a production target of $600 \mathrm{pcs}$ each line with a total production target of 2400 pcs. However, the desired targets are often not able to be achieved which affects the delay in delivery of products to customers. Based on the observation, some causes identified are work stations cutting, sewing, and preparation before sewing (PSP) as a core process in the production of golf gloves. The root causes of waste consist of these following wait time situations: (1) waste of production lead-time due to delaying of raw materials from suppliers; (2) waste of defect product due to inaccuracy or incorrect execution by operator so the defect products have to be reworked; and (3) waste of iinappropriate processing and unnecessary motion caused by indiscipline and lack of skilled operators.

To enhance productivity, the company should be able to improve the production process by eliminating all nonvalue added activities int their plants using the application of lean manufacturing [1]. Value stream mapping is a set of methods to map activity in the application of lean manufacturing production [2]. It has also been applied to analyse the flow of production as well as eliminating or minimizing non-value adding activities [3]. While lean concepts with value stream mapping approach is proved to be effectively implemented on the production floor [4]. On the other hand, lean manufacturing can be used as a good strategy of process improvements and an alternative to increase the production output without a big amount of investment [5].

In order to overcome the waste occured in process above, this study aims to determine the value-added activities, non-value added activities, nnecessary but nonvalue added (NNVA) activityies, and to propose an improvement of each identified major waste using VSM tools .

\section{Literature Review}

\subsection{Lean Manufacturing}

Lean manufacturing is every activityy described in a timeline begun with customer demand pushing towards producer, which aims to reduce lead-time by eliminating waste or removing activities that contribute no value to the product produced from the arrival of raw materials from suppliers to the customers' final product through continuous improvement method [6]

\subsection{Waste}

Waste is any activity that consumes time, resources and space but do not contribute to satisfying the needs of cos [7]. There are 7 types of wastes occured in the manufacturing process [8]:

1. Overproduction

Overproduction, where production exceeds customer demand, is considered the most harmful waste as it itself creates additional waste including excess inventory and transportation.

2. Defect

Defects are products or services that are out of specification. They need extra effort to fix and lead directlyto increased costs and lost time, either through repairs or having start over.

\footnotetext{
* Corresponding author: halimatussadiah13522198@gmail.com
} 
3. Unnecessary Inventory

Inventory, such as raw materials, work-in-progress or goods which are sitting idle, is considered waste as it has not yet contributed value to the end customer.

4. Inappropriate processing

Innappropriate processing or excess process is any activity that is not needed to produce a functioning product or service and can occur due to unnecessarily drawn-out processes.

5. Excessive transportation

Transportation occurs whenever products are transported from one location to another. This can increase the risk of damages, additional waiting time and costs.

6. Waiting

Waiting occures whenever items are not in transport or being processed. For example, employees wait for materials, equipment waits for maintenance, or work in process waits for the employee to return.

7. Unnecessary Motion

Unnecessary motion can occur due to insufficient layouts or searching for mislaid items. It can also increase the risk of damage to equipment or cause employee injuries.

\subsection{Value Stream Mapping (VSM)}

Value Stream Mapping (VSM) is a tool used to map the value stream and identify any waste that add value and do not add value [2]. VSM is used to increase the cycle time by showing how the actual operating process in every activity with time details. VSM can be used to analyse the process and performance improvement by identifying and reducing the time utilization on non-value-added activities [9].

\section{Methodology}

The method used is the approach of lean manufacturing and value stream mapping. Primary data is obtained by employing interviews, documentation using video recorder, and a stopwatch to create the Current State Value Mapping. For creating the Current State Value Mapping, data needed are the production process of the research object, the cycle time, the number of available time, and waste identification using 7 types of waste. While the secondary data is referred to the company production data. The next step is developing a Future State of Value Mapping using the current state value map which the major wastes have been reduced.

\section{Data Analysis}

\subsection{Current State Value Mapping}

The Current state map (CSM) charts the present flow of information and material as product goes through the manufactuing process. This is vital both to understand the need for change and to understand where opportunities lie. CSM is a condition that is used to identify the waste for the repair and improvement of a company [10]. To develop CSM, we conduct a direct observation and interviews with the head of production who understand the most of PT.XYZ production. There are several golf gloves with the similar processes. Yet, they have different level of complexity in the form of variations and fantasies so Lucky 39 is chosen as the object of this study. The data of operator and available time in producing golf gloves can be seen in Table 1.

Table 1. Data of operator and available time

\begin{tabular}{|c|c|c|}
\hline Proses & Operator & $\begin{array}{c}\text { Available } \\
\text { Time }\end{array}$ \\
\hline Cutting & 12 & 25200 \\
\hline PSP & 60 & 25200 \\
\hline Sewing & 82 & 25200 \\
\hline
\end{tabular}

Current state value mapping of golf gloves based on the data proceeded showed in Figure 1.



Fig 1. Current state mapping section sanding model A

\subsection{Waste Identification}

There are 5 wastes identified in the process of cutting, PSP, and sewing:

1. Defects: Throughout 2016, there were 369 pcs wrong cut product in the cutting process and 2228 pcs of defective products in the sewing process.

2. Unnecessary inventory: excess materials stored for reuse.

3. Inappropriate processing: It is caused by human error, the less scrupulous operators to inspect the products and raw materials as well as the presence of broken machines when the production processes proceed that disrupt the operators' works.

4. Waiting: delayed delivery of raw materials from suppliers, operators are not discipline, and production capacity is not appropriate.

5. Unnecessary motion: The undisciple operators who do a lot of activities outside of their main job such as a lot of chat among operators, take a drink frequently, and go to the bathroom for some time. 


\subsection{Future State Value Mapping}

The future state value mapping or Future State Map (FSM) is a chart that suggests how to create a lean flow. It is a picture that will be used in the future and has been fixed from the current state value mapping [10]. The FSM is used to help make decisions which create future process improvements. The picture of the future state mapping is as follows:

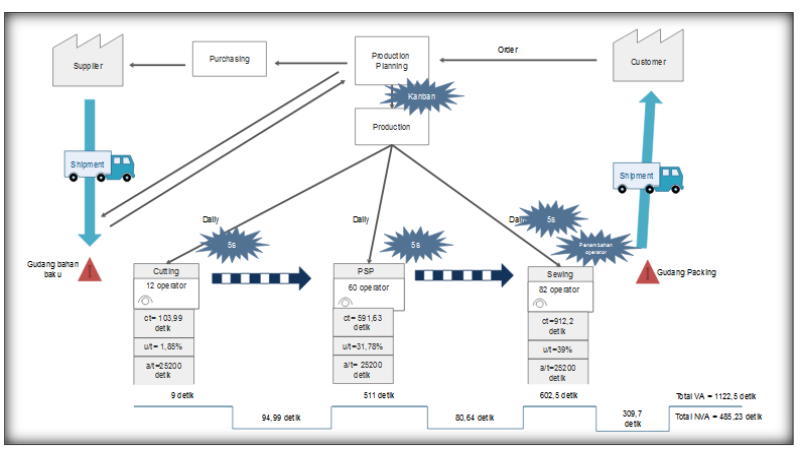

Fig 2. Current state mapping section sanding model A

\section{Result and Discussion}

According to the current state value mapping in Figure 1, it is known that lead time in producing a golf gloves is as much as 2048.21 seconds. The output produced by the company is 1902 pcs, which is lack of 498 pcs production (20.73\%) of the company's target. The future state value in Figure 2 showed the lead time of 1607.81 seconds. The decreasing lead time of 440.4 seconds is due to the reduction of non-value added activities. To achieve the target of 2400 pcs in the cutting process, the number of operators required is 10 people, 57 operators in PSP, and 87 operators in the sewing process. Therefore, in order to overcome these problems, 2 operators of the cutting process and 3 operators of the PSP will be moved to the sewing process. With this operator, transferring, sewing training is highly required for new/backup operators. Here is a comparison between the current state and future state value mapping.

Table 2. The comparison between CSM and FSM

\begin{tabular}{|l|c|c|c|}
\hline Comparison & Current state & Future state & Improvements \\
\hline Lead time & $2048,21(\mathrm{~s})$ & $1607,81(\mathrm{~s})$ & $440,4(\mathrm{~s})$ \\
\hline $\begin{array}{l}\text { Non value } \\
\text { added }\end{array}$ & $925,76(\mathrm{~s})$ & $440,41(\mathrm{~s})$ & $485,25(\mathrm{~s})$ \\
\hline Output & $1902,41 \mathrm{pcs}$ & $2403,94 \mathrm{pcs}$ & $501,53 \mathrm{pcs}$ \\
\hline Persentase & $79,27 \%$ & $100,16 \%$ & $20,89 \%$ \\
\hline
\end{tabular}

The comparison in Figure 2 indicates a 440.4 seconds lead time reduction in the critical areas of defects, unnecessary inventory, inappropriate processing, waiting, and unnecessary motion. The productivity increased 502 pcs or is up t0 $21 \%$ so the company's target can be reached. These improvements are gained by removing non-value added activities including waste. In the cutting process, the discharged non-added value activities are: (1) calculating the amount of the pattern. Since the inspection section has already done it, so the operator does not need to perform this activity again. (2) Sharpening blade can be removed by purchasing a new blade. (3) Searching stationeries can be eliminated by applying the principles of $5 \mathrm{~S}$ so the operator may spend less time. (4) Recording quantities can be eliminated using kanban or it will be recorded by administrative staff or section leader, not the operator. In the PSP process, there are several non-added activities consisted of sewing machine preparation, ribbon rolls separation, thread repairing, checking, repairing fantasy omo face, and ribbon rolls separation. They are part of Inappropriate processing and Uunnecessary motion. The sewing machine repairing can be removed by a regular maintenance. Whereas in the sewing process, the nonadded value are checking, separating winding thread, and place the ribbon. These are Inappropriate processing and Uunnecessary motion. The activities of seeking machi size, taking or separating folding omo, and placing or separating can be removed by applying $5 \mathrm{~s}$. Labeling every machi size and providing information on any work in process (WIP) will guide the operator to look for or separate WIP. Some of the proposed improvements of the identified wastes are clearly explained in Table 3.

Table 3. The proposed improvements of identified wastes

\begin{tabular}{|c|c|c|}
\hline Causes & Impacts & $\begin{array}{l}\text { Proposed } \\
\text { improvement }\end{array}$ \\
\hline $\begin{array}{l}\text { Less scrupulously } \\
\text { operator }\end{array}$ & $\begin{array}{l}\text { Defect } \\
\text { Inappropriate } \\
\text { processing } \\
\text { Waiting }\end{array}$ & $\begin{array}{l}\text { - The leader must } \\
\text { conduct a strict } \\
\text { supervision } \\
\text { whenever the } \\
\text { operator loose } \\
\text { focus particularly } \\
\text { after break time } \\
\text { and work is almost } \\
\text { over } \\
\text { - The leader must } \\
\text { conduct a regular } \\
\text { and random } \\
\text { checking }\end{array}$ \\
\hline $\begin{array}{l}\text { Less focus } \\
\text { operator }\end{array}$ & $\begin{array}{l}\text { Defect } \\
\text { Waiting } \\
\text { Inappropriate } \\
\text { processing }\end{array}$ & $\begin{array}{l}\text { - Adding break time } \\
\text { - Design a particular } \\
\text { chair for pressing } \\
\text { activity in cutting } \\
\text { process }\end{array}$ \\
\hline $\begin{array}{l}\text { Undiscipline } \\
\text { operator }\end{array}$ & $\begin{array}{l}\text { Waiting } \\
\text { Inappropriate } \\
\text { processing } \\
\text { Unnecessary } \\
\text { motion }\end{array}$ & $\begin{array}{l}\text { - Motivate and } \\
\text { encourage them, } \\
\text { and evaluate the } \\
\text { working } \\
\text { performance before } \\
\text { production process } \\
\text { started } \\
\text { - The leader must } \\
\text { strictly warn the } \\
\text { undiscipline } \\
\text { operator } \\
\text { - Provide a reward } \\
\text { and punishment for } \\
\text { discipline and }\end{array}$ \\
\hline
\end{tabular}




\begin{tabular}{|c|c|c|}
\hline Causes & Impacts & $\begin{array}{l}\text { Proposed } \\
\text { improvement }\end{array}$ \\
\hline & & $\begin{array}{l}\text { undiscipline } \\
\text { operator }\end{array}$ \\
\hline $\begin{array}{l}\text { Lack of skilled } \\
\text { operator }\end{array}$ & $\begin{array}{l}\text { Waiting } \\
\text { Inappropriate } \\
\text { processing } \\
\text { Unnecessary } \\
\text { motion } \\
\text { Defect }\end{array}$ & $\begin{array}{l}\text { - Conduct a } \\
\text { continous training } \\
\text { for every operator. } \\
\text { It will be useful to } \\
\text { leverage the skill as } \\
\text { well as refresh the } \\
\text { energy in order to } \\
\text { improve the } \\
\text { working } \\
\text { performance } \\
\text { - Add a new } \\
\text { requirement when } \\
\text { recruiting a new } \\
\text { operator such as } \\
\text { experience in } \\
\text { sewing process }\end{array}$ \\
\hline Broken machine & $\begin{array}{l}\text { Waiting } \\
\text { Inappropriate } \\
\text { processing } \\
\text { Unnecessary } \\
\text { motion } \\
\text { Defect } \\
\end{array}$ & $\begin{array}{l}\text { - Routine } \\
\text { maintenance } \\
\text { - Purchase a new } \\
\text { tool/machine }\end{array}$ \\
\hline $\begin{array}{l}\text { Delay delivery of } \\
\text { raw materials }\end{array}$ & Waiting & $\begin{array}{l}\text { Renew the suppliers' } \\
\text { contracts so they } \\
\text { will deliver the } \\
\text { materials needed } \\
\text { on schedule }\end{array}$ \\
\hline $\begin{array}{l}\text { Uncomfortable/un } \\
\text { clean working } \\
\text { environment }\end{array}$ & $\begin{array}{l}\text { Defect } \\
\text { Inappropriate } \\
\text { processing }\end{array}$ & $\begin{array}{l}\text { - Add the cleaning } \\
\text { service staff at the } \\
\text { production floor } \\
\text { - Implement 5s } \\
\text { methods } \\
\text { consistently. }\end{array}$ \\
\hline
\end{tabular}

\section{Conclusion and Recommendation}

\subsection{Conclusion}

1. The current state mapping value shows 28 value added activities, 55 non-value added activities, and 7 necessary but non-value added activities. While on the future state mapping value, 17 non-value added activities have been reduced.

2. It is obtained a 1607.8 seconds lead time using the future state value mapping. By reducing the non-value added activities, the FSM has indicated a decreasing lead time of 440.4 seconds. Thus, it will increase the output of $502 \mathrm{pcs}$ as well as the increasing productivity can be achieved from $79.27 \%$ to more than $100 \%$.

3. The major root causes of identified wastes are less scrupulously operator, less focus operator, undiscipline operator, lack of skilled operator, the broken machine, delay delivery of raw materials, and uncomfortable/unclean working environment.

\subsection{Recommendation}

Future research should look at simulation of the proposed improvements combining with the cost consideration, downtime machine, and other factors to eliminate waste that would contribute positively to the bottom line.

\section{References}

1. Bhati, S. \& Porwal, S., A Case Study on Improving Process and Eliminating Waste through Lean Manufacturing Techniques, 3 (12), pp.3-6 (2015)

2. Taylor, P., Gupta, S. \& Jain, S.K., Literature review of lean manufacturing. International Journal of Management Science and Engineering Management, (November 2014), pp.37-41 (2013)

3. Ar, R. \& Al-Ashraf, M., Production Flow Analysis through Value Stream Mapping: A Lean Manufacturing Process Case Study. , 41(Iris), pp.1727-1734. Available at: http://dx.doi.org/10.1016/j.proeng.2012.07.375 (2012)

4. Goriwondo, W.M., Mhlanga, S. \& Marecha, A., Use of the Value Stream Mapping Tool for Waste Reduction in Manufacturing. Case Study for Bread. , pp.236-241 (2011)

5. Murugesan, M., Rajenthirakumar, D. \& Chandrasekar, M., Manufacturing Process Improvement Using Lean Tools. Annals of faculty Engineering Hunedoara International Journal of Engineering, pp.151-154 (2016)

6. Ohno, T., 1995. Toyota Production System, Beyond Large-Scale Production. Terjemahan:

7. Liker, J.K. \& Mcgraw-hill, T., The Toyota Way (2004)

8. Liker, J. \& Meier, D., The Toyota Way Fieldbook (2006)

9. Capital, M., Introduction to Lean Manufacturing for Vietnam. , (June), pp.1-20 (2004)

10. Tilak, Minakshi, Aken, E. V., McDonald, T., \& Kannan, R. Value Stream Mapping: A Review and Comparative Analysis of Recent Applications (2010) 